\title{
PENGARUH DESKRIPSI PEKERJAAN, PENGAWASAN DAN PENGEMBANGAN KARIR TERHADAP KOMITMEN ORGANISASI POLISIDI KEPOLISIAN RESOR LABUHANBATU
}

\author{
${ }^{1}$ Solihuddin Hasibuan, ${ }^{2}$ Zainal Abidin, ${ }^{3}$ Aca Ciputri Cis, ${ }^{4}$ Zainan Nur, ${ }^{5}$ Nurmalan Harahap \\ $1,2,3,4,5$ Universitas Islam Sumatera Utara \\ Isolihuddin.hsb@gmail.com, 2zainal.abidin@gmail.com,33aca.ciputricis@gmail.com, \\ ${ }^{4}$ zainan.nur@gmail.com, ${ }^{5}$ nurmalan.hrp@gmail.com
}

\begin{abstract}
This research aims to determine and analyze : 1) the effect of job descriptions on the commitment of the Police organization in Labuhanbatu District Police; 2) the effect of supervision on the commitment of the Police organization in Labuhanbatu District Police; 3) the influence of career development on the commitment of the Police organization in Labuhanbatu District Police; and 4) job description, supervision and career development towards the commitment of the Police organization in Labuhanbatu District Police. The sample in this research amounted to 75 people with sample monitoring techniques using the stratified random sampling method. The results showed : 1) the job description had a positive and significant effect on the commitment of the police organization in Labuhanbatu District Police; 2) supervision has a positive and significant impact on the commitment of police organizations in Labuhanbatu District Police; 3) career development has a positive and significant impact on the commitment of police organizations in Labuhanbatu District Police; 4) simultaneous job description, supervision and career development have a positive and significant effect on the commitment of the police organization in Labuhanbatu District Police. The commitment of police organizations can be influenced by job description, supervision and career development by $64.7 \%$, while the remaining $35.3 \%$ organizational commitment is influenced by other factors outside the research variable.
\end{abstract}

Keywords : Job Description, Supervision, Career Development, Organizational Commitment.

ABSTRAK : Penelitian ini bertujuan untuk mengetahui dan menganalisis : 1) pengaruh deskripsi pekerjaan terhadap komitmen organisasi Polisi di Kepolisian Resor Labuhanbatu; 2) pengaruh pengawasan terhadap komitmen organisasi Polisi di Kepolisian Resor Labuhanbatu; 3) pengaruh pengembangan karir terhadap komitmen organisasi Polisi di Kepolisian Resor Labuhanbatu; dan 4) deskripsi pekerjaan, pengawasan dan pengembangan karir terhadap komitmen organisasi Polisi di Kepolisian Resor Labuhanbatu. Sampel dalam penelitian ini berjumlah 75 orang dengan teknik penantuan sampel menggunakan metode stratified random sampling. Hasil penelitian menunjukkan : 1) deskripsi pekerjaan berpengaruh positif dan signifikan terhadap komitmen organisasi polisi di Kepolisian Resor Labuhanbatu; 2) pengawasan berpengaruh positif dan signifikan terhadap komitmen organisasi polisi di Kepolisian Resor Labuhanbatu; 3) pengembangan karir berpengaruh positif dan signifikan terhadap komitmen organisasi polisi di Kepolisian Resor Labuhanbatu; 4) deskripsi pekerjaan, pengawasan dan pengembangan karir secara simultan berpengaruh positif dan signifikan terhadap komitmen organisasi polisi di Kepolisian Resor Labuhanbatu. Komitmen organisasi polisi dapat dipengaruhi oleh deskripsi pekerjaan, pengawasan dan pengembangan karir sebesar $64,7 \%$, sedangkan sisanya 35,3\% komitmen organisasi dipengaruhi oleh faktor-faktor lain diluar variabel penelitian.

Kata kunci :Deskripsi pekerjaan, Pengawasan, Pengembangan karir, Komitmen organisasi.

\section{Pendahuluan}

Kegiatan organisasi tidak akan berjalan tanpa adanya keterlibatan unsur manusia yang ada didalamnya. Unsur pengendalian ada pada manusia, sehingga pada akhirnya dibanding dengan faktor-faktor yang lain, maka manusia merupakan unsur yang paling menentukan keberhasilan atau kegagalan suatu organisasi 
dalam menyelenggarakan berbagai kegiatan dalam rangka pencapaian tujuan dan berbagai sasaran organisasi. Tercapainya tujuan suatu lembaga atau organisasi tidak hanya tergantung pada peralatan modern, sarana dan prasarana yang lengkap, tetapi justru lebih tergantung pada manusia yang melaksanakan pekerjaan tersebut. Oleh karena itu, pada lingkungan instansi, pegawai yang berkualitas adalah pegawai yang melaksanakan pekerjaannya dan mampu memberikan hasil kerja yang baik atau mempunyai komitmen kerja yang tinggi yang dibutuhkan oleh instansi untuk mencapai tujuan.

Pegawai yang memiliki komitmen yang tinggi pada organisasinya, biasanya akan memberikan seluruh kemampuan dan keterampilannya untuk perusahaan tempat ia bekerja agar organisasi tersebut mencapai tujuannya dan berjalan kearah yang lebih baik lagi, dan tentunya juga berpengaruh terhadap meningkatnya kinerja pada karyawan tersebut. Dengan kata lain bahwa komitmen merupakan rasa keterikatan pegawai, serta pemberian dukungan penuh yang dilakukan pegawai terhadap organisasi tempatnya bekerja.

Untuk membentuk komitmen pegawai terhadap organisasi diperlukan berbagai factor pendukung, diantaranya adalah deskripsi pekerjaan (job description) yang jelas dan adanya pengawasan kerja. Deskripsi pekerjaan merupakan uraian tugas-tugas, kewajibankewajiban, dan tanggung jawab dari suatu pekerjaan. Deskripsi pekerjaan yang disusun dengan jelas sesuai dengan hak dan kewajiban yang ditetapkan akan mempermudah pegawai memahami apa yang harus dikerjakan. Informasi pekerjaan yang tertulis pada deskripsi pekerjaan apabila dipahami dan dilaksanakan dengan baik akan mendorong pegawai untuk melaksanakan pekerjaan dengan efektif sehingga dampaknya pada prestasi kerja juga akan semakin baik.

Selain deskripsi pekerjaan, hal yang perlu diperhatikan bagi sebuah organisasi adalah pengawasan. Pengawasan proses pemantauan, penilaian dan pelaporan rencana atas pencapaian tujuan yang telah ditetapkan untuk tindakan korektif guna penyempurnaan tugas lebih lanjut. Pengawasan juga merupakan bagian terakhir dari fungsi manajemen karena dapat mengetahui apakah ada penyimpangan dalam pelaksanaan kegiatan yang berlangsung dalam suatu organisasi.
Adanya kesempatan pengembangan karir mendukung inisiatif komitmen karir antara karyawan (Adekola, 2011). Untuk itu sistem pengembangan karir yang ditawarkan perusahaan merupakan salah satu cara untuk merangsang sikap komitmen karyawan. Karena hal tersebut merupakan jawaban agar kayawan mampu menerima tugas yang lebih sulit dan tanggung jawab yang lebih besar serta posisi yang lebih baik di perusahaan. Pengembangan karir tidak hanya sebagai jalan bagi karyawan untuk mendapatkan apa yang mereka inginkan namun juga untuk membuat karyawan mampu untuk berada pada jenjang karir tertentu yang membuat perubahan kearah positif dalam karir mereka. Dengan pengembangan karir diharapkan juga dapat mencapai tingkat kepuasan yang lebih tinggi, dikarenakan perusahaan akan berusaha untuk menumbuhkan kepuasan kerja yang sehat dimana hak dan kewajiban karyawan diatur sedemikian rupa selaras dengan fungsi, peranan, dan tanggung jawab karyawannya sehingga karyawan dapat berpartisipasi dalam perusahaan (Septyawati, 2010).

Kepolisian Resor Labuhanbatu (Polres Labuhanbatu) merupakan salah satu unsur kepolisian dibawah Kepolisian Daerah Sumatera Utara yang mempunyai wilayah hukum membawahi 3 (tiga) Kabupaten yaitu Kabupaten Labuhanbatu, Kabupaten Labuhanbatu Utara dan Kabupaten Labuhanbatu Selatan. Dalam melaksanakan tugas dan fungsinya dalam bidang, Kepolisian Resor Labuhanbatu didukung oleh sumber daya manusia yang terdiri atas anggota Polri dan Pegawai Negeri Sipil. Dengan wilayah hukum yang luas tersebut, personil Polres Labuhanbatu dituntut untuk memiliki komitmen yang tinggi dalam memberikan pelayanan prima kepada masyarakat dan seluruh pemangku kepentingan.

Setiap anggota Polisi sudah mempunya deskripsi pekerjaan masing-masing yang mengacu pada prosedur tetap (Protap) yang berlaku, meskipun belum sepenuhnya berjalan efektif. Permasalahan tersebut dapat dilihat dari adanya personil yang kurang memahami tugas pokok dan fungsi (tupoksi) nya, ada pula personil yang melaksanakan tupoksi personil lain sehingga terjadi tumpang tindih pekerjaan. Hal ini menurut penulis disebabkan kurang jelasnya deskripsi pekerjaan setiap personil atau bisa juga disebabkan personil yang kurang memahami deskripsi pekerjaannya. 
Berkaitan dengan pengawasan tentunya insititusi Polisi sudah memiliki sistem pengawasan yang ketat dan mengikat bagi setiap anggota Polisi. Sistem pengawasan dilakukan secara berjenjang dan terstruktur, yang mana didalam pengawasan internal, setiap personil Polisi dalam mengerjakan pekerjaannya diawasi oleh atasan langsung (komandan). Periode pengawasan juga dilakukan secara rutin. Akan tetapi dalam praktiknya terkadang atasan kurang memberikan perhatian kepada personil.

Sistem pengembangan karir di Kepolisian dilakukan secara berjenjang dan terintegrasi mulai dari pusat hingga ke daerah. Setiap anggota Polisi memiliki kesempatan untuk menduduki jabatan tertentu jika pangkat sudah memenuhi syarat dan berdasarkan hasil penilaian dari pimpinan. Persaingan pasti terjadi karena posisi jabatan yang ada diperebutkan oleh beberapa orang. Dalam hal ini untuk memenangkan persaingan tentunya anggota Polisi harus memiliki value dibandingan Polisi yang lain dan memiliki skill yang khusus yang dibutuhkan insititusi yang bisa menjadi pertimbangan pimpinan. Untuk itu anggota polisi harus berusaha meningkatkan kompetensi diri, misalnya melalui peningkatan jenjang pendidikan atau mengikuti kursus/diklat yang dapat menambah kemampuan. Akan tetapi tidak semua Polisi memiliki semangat, motivasi dan keinginan untuk itu dan merasa cukup dengan apa yang ada saat ini.

\subsection{Batasan Masalah}

Batasan atau ruang lingkup masalah dalam penelitian ini adalah pada pengaruh deskripsi pekerjaan, pengawasan dan pengembangan karir terhadap komitmen organisasi Polisi di Kepolisian Resor Labuhanbatu.

\subsection{Hioptesis}

Hipotesis merupakan jawaban sementara yang disusun oleh peneliti, yang kemudian akan diuji kebenarannya melalui penelitian yang dilakukan (Kuncoro, 2013:59). Hipotesis adalah jawaban sementara terhadap suatu masalah yang sedang diselidiki kebenarannya dan masih memerlukan pembuktian. Hipotesis peneliti yaitu :

1) Deskripsi pekerjaan berpengaruh positif dan signifikan terhadap komitmen organisasi polisi di Kepolisian Resor Labuhanbatu.

2) Pengawasan berpengaruh berpengaruh positif dan signifikan terhadap komitmen organisasi polisi di Kepolisian Resor Labuhanbatu.

3) Pengembangan karir berpengaruh berpengaruh positif dan signifikan terhadap komitmen organisasi polisi di Kepolisian Resor Labuhanbatu.

4) Deskripsi pekerjaan, pengawasan dan pengembangan karir berpengaruh positif dan signifikan terhadap komitmen organisasi polisi di Kepolisian Resor Labuhanbatu.

\subsection{Tujuan Penelitian}

Adapun tujuan dari penelitian ini adalah :

1) Untuk mengetahui dan menganalisis pengaruh deskripsi pekerjaan terhadap komitmen organisasi Polisi di Kepolisian Resor Labuhanbatu.

2) Untuk mengetahui dan menganalisis pengaruh pengawasan terhadap komitmen organisasi Polisi di Kepolisian Resor Labuhanbatu.

3) Untuk mengetahui dan menganalisis pengaruh pengembangan karir terhadap komitmen organisasi Polisi di Kepolisian Resor Labuhanbatu.

4) Untuk mengatahui pengaruh deskripsi pekerjaan, pengawasan dan pengembangan karir terhadap komitmen organisasi Polisi di Kepolisian Resor Labuhanbatu.

\section{Metode Penelitian}

\subsection{Populasi}

Populasi merupakan keseluruhan unit atau individu dalam ruang lingkup dan waktu yang ingin diteliti (Durianto et al, 2013:26). Populasi pada penelitian ini adalah seluruh polisi di Kepolisian Resor Labuhanbatu yang berjumlah 353 orang.

Tabel 1. Personil Polres Labuanbatu

\begin{tabular}{|c|l|c|}
\hline No & \multicolumn{1}{|c|}{ Satuan Fungsi } & Jumlah \\
\hline 1 & Bagian operasional & 12 \\
\hline 2 & Bagian Perencanaan & 11 \\
\hline 3 & Bagian Sumda & 10 \\
\hline 4 & Sat Intelkam & 32 \\
\hline 5 & Sat Reskrim & 30 \\
\hline 6 & Sat Resnarkoba & 31 \\
\hline 7 & Sat Lantas & 36 \\
\hline 8 & Sat Binmas & 17 \\
\hline 9 & Sat Sabhara & 24 \\
\hline 10 & Sat Tahti & 17 \\
\hline 11 & Sat Polair & 28 \\
\hline 12 & Siwas & 25 \\
\hline
\end{tabular}




\begin{tabular}{|c|l|c|}
\hline No & Satuan Fungsi & Jumlah \\
\hline 13 & Sitipol & 13 \\
\hline 14 & Sipropam & 28 \\
\hline 15 & Sikeu & 13 \\
\hline 16 & Sium & 15 \\
\hline 17 & SPKT & 11 \\
\hline \multicolumn{2}{|c|}{ Total } & $\mathbf{3 5 3}$ \\
\hline
\end{tabular}

Sumber : Polres Labuhanbatu (2020)

\subsection{Sampel}

Sampel adalah suatu himpunan bagian dari unit populasi (Sugiyono, 2012:16). Pengambilan sampel dalam penelitian ini terdiri atas anggota polisi di Polres Labuhanbatu. Penarikan sampel menggunakan teknik Stratified Random Sampling dengan penentuan ukuran sampel berdasarkan rumus Slovin (Umar, 2013) sebagai berikut :

$$
\mathrm{n}=\frac{N}{1+N e^{2}}
$$

Keterangan :

$\mathrm{n}$ = Jumlah Sampel

$\mathrm{N}=$ Jumlah Populasi

$e=$ Tingkat Kesalahan (persen kelonggaran ketidaktelitian karena kesalahan penarikan sampel).

Berdasarkan formula diatas, selanjutnya dapat dihitung jumlah sampel dalam penelitian ini sebagai berikut :

$$
\begin{gathered}
\mathbf{n}=\frac{353}{1+353(0,1)^{2}} \\
\mathbf{n}=\frac{353}{4,53} \\
\mathbf{n}=\mathbf{7 7 , 9 2}=\mathbf{7 8} \text { orang }
\end{gathered}
$$

Setelah perhitungan di atas, penetapan jumlah sampel dalam penelitian ini menggunakan metode stratified random sampling yaitu penarikan sampel berdasarkan pada strata populasi pada setiap bagian, sehingga sampel dalam penelitian ini berjumlah 78 orang pegawai, dengan rincian sebagai berikut :

Tabel 2. Distribusi Sampel Penelitian

\begin{tabular}{|c|l|c|}
\hline No & \multicolumn{1}{|c|}{ Satuan Fungsi } & Jumlah \\
\hline 1 & Bagian operasional & 3 \\
\hline 2 & Bagian Perencanaan & 2 \\
\hline 3 & Bagian Sumda & 2 \\
\hline 4 & Sat Intelkam & 7 \\
\hline 5 & Sat Reskrim & 7 \\
\hline 6 & Sat Resnarkoba & 7 \\
\hline
\end{tabular}

\begin{tabular}{|c|l|c|}
\hline No & \multicolumn{1}{|c|}{ Satuan Fungsi } & Jumlah \\
\hline 7 & Sat Lantas & 8 \\
\hline 8 & Sat Binmas & 4 \\
\hline 9 & Sat Sabhara & 5 \\
\hline 10 & Sat Tahti & 4 \\
\hline 11 & Sat Polair & 6 \\
\hline 12 & Siwas & 6 \\
\hline 13 & Sitipol & 3 \\
\hline 14 & Sipropam & 6 \\
\hline 15 & Sikeu & 3 \\
\hline 16 & Sium & 3 \\
\hline 17 & SPKT & $\mathbf{7 8}$ \\
\hline \multicolumn{2}{|c|}{ Total }
\end{tabular}

\subsection{Uji Normalitas}

Uji normalitas bertujuan untuk menguji apakah nilai residual berdistribusi normal atau tidak, yang dapat dilakukan melalui beberapa pendekatan yaitu :

a) Pendekatan histogram

Pada grafik histogram, dikatakan variabel berdistribusi normal pada grafik histogram yang berbentuk lonceng apabila distribusi data tersebut tidak menceng kekiri atau menceng kekanan.

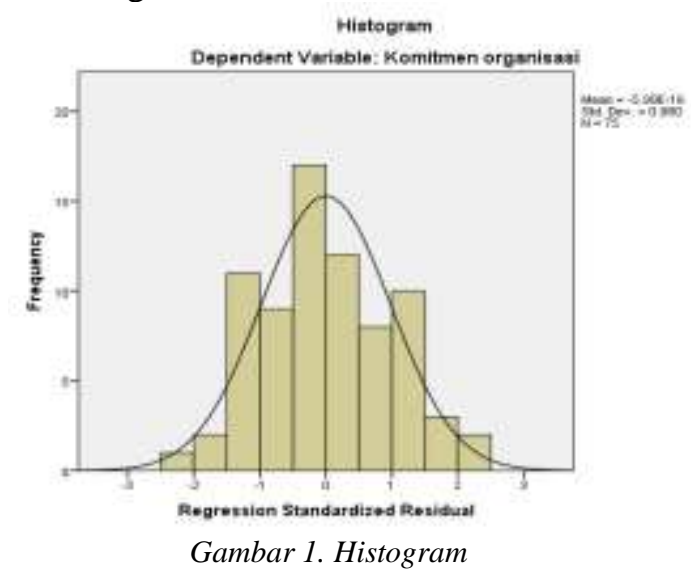

Pada grafik histogram terlihat bahwa variabel berdistribusi normal hal ini ditunjukkan oleh distribusi data tersebut tidak menceng ke kiri atau menceng ke kanan.

\section{b) Pendekatan Grafik}

Cara lainnya melihat uji normalitas dengan pendekatan grafik. PP plot akan membentuk plot antara nilai-nilai teoritis (sumbu $\mathrm{X}$ ) melawan nilai-nilai yang didapat dari sampel (sumbu Y). Apabila plot keduanya berbentuk linier (dapat didekati oleh garis lurus), maka hal 
ini merupakan indikasi bahwa residual menyebar normal.

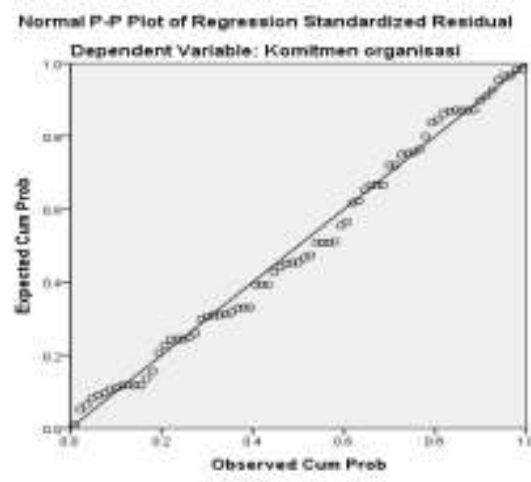

Gambar 2. Grafik Normal PP plot
Pada gambar 2 grafik nomal PP Plot terlihat titik yang mengikuti data di sepanjang garis diagonal. Hal ini berarti data berdistribusi normal.

c) Uji Kolmogorov-Smirnov

Tabel 3 Uji Kolmogorov-Smirnov

One-Sample Kolmogorov-Smirnov Test

\begin{tabular}{|ll|r|}
\hline & & $\begin{array}{c}\text { Unstandardized } \\
\text { Residual }\end{array}$ \\
\hline $\mathrm{N}$ & Mean & 75 \\
Normal Parameters ${ }^{\mathrm{a}, \mathrm{b}}$ & Std. Deviation & 1.02588255 \\
& Absolute & .075 \\
Most Extreme Differences & Positive & .075 \\
& Negative & -.056 \\
Kolmogorov-Smirnov Z & & .648 \\
Asymp. Sig. (2-tailed) & & .796 \\
\hline a. Test distribution is Normal. & & \\
b. Calculated from data. &
\end{tabular}

Melalui Tabel 3 terlihat bahwa nilai Asymp. Sig. (2-tailed) adalah 0,796>0,05 Dengan demikian maka data residual berdistribusi normal. Nilai KolmogorovSmirnov $\mathrm{Z}$ adalah $0,648>0,05$ berarti tidak ada perbedaan antara distribusi teoritik dan distribusi empirik atau dengan kata lain data terdistribusi normal.

\subsection{Uji Multikolinearitas}

Untuk mengetahui ada tidaknya gejala multikolinearitas dapat dilihat dari besarnya nilai tolerance dan VIF (Variance Inflation Factor) melalui program SPSS. Tolerance mengukur variabilitas variabel terpilih yang tidak dijelaskan oleh variabel independen lainnya. Nilai umum yang bisa dipakai adalah nilai Tolerance $>0,1$ atau nilai VIF $<5$, maka tidak terjadi multikolinearitas. Hasil pengolahan dapat dilihat pada Tabel 4 :

Tabel 4. Hasil Uji Multikolinearitas

\begin{tabular}{|c|c|c|c|}
\hline \multirow{2}{*}{\multicolumn{2}{|c|}{ Model }} & \multicolumn{2}{|c|}{ Collinearity Statistics } \\
\hline & & Tolerance & VIF \\
\hline \multirow{4}{*}{1} & (Constant) & & \\
\hline & Deskripsi pekerjaan & .787 & 1.271 \\
\hline & Pengawasan & .720 & 1.388 \\
\hline & Pengembangan karir & 658 & 1.520 \\
\hline
\end{tabular}

Berdasarkan Tabel 4 diketahui bahwa semua variabel independen memiliki nilai Tolerance $>0,1$ dan nilai $\mathrm{VIF}<5$. Artinya bahwa tidak terjadi masalah multikolinearitas pada masing-masing variabel bebasnya.

\subsection{Uji Heteroskedostisitas}

Alat untuk menguji heterokedastisitas dapat dibagi dua yaitu dengan dengan alat analisis grafik (scatter plot). Heterokedastisitas dapat juga dilihat melalui gambar scatter plot. Gambar scatter plot dapat mengindikasi ada atau tidaknya gejala heterokedastisitas. Apabila 
grafik tidak membentuk pola yang jelas maka tidak mengalami gangguan heterokedastisitas.

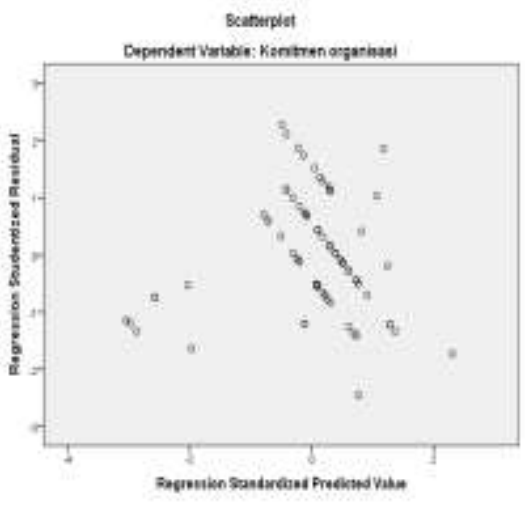

Gambar 3 Scatterplot titik yang berpencar. Kesimpulan yang dapat diperoleh adalah tidak terdapat gejala heterokedastisitas, sehingga model regresi layak dipakai untuk memprediksi komitmen organisasi berdasarkan masukan variabel deskripsi pekerjaan, pengawasan dan. Pengembangan karir

Pendekatan lain yang dapat digunakan dalam melakukan uji heteroskedostisitas adalah dengan Uji Glejser. Kriteria pengambilan keputusannya adalah jika nilai signifikansi > 0,05 maka tidak mengalami gangguan heterokedastisitas. Sedangkan jika nilai signifikansi $<0,05$ maka mengalami gangguan heterokedastisitas.

Gambar.3 menunjukkan bahwa penyebaran residual cenderung tidak teratur, terdapat titik-

Tabel 5. Hasil Uji Glejser

Coefficients $^{\mathbf{a}}$

\begin{tabular}{|c|c|c|c|c|c|}
\hline \multirow[t]{2}{*}{ Model } & \multicolumn{2}{|c|}{$\begin{array}{c}\text { Unstandardized } \\
\text { Coefficients }\end{array}$} & $\begin{array}{c}\text { Standardized } \\
\text { Coefficients }\end{array}$ & \multirow[t]{2}{*}{$\mathrm{t}$} & \multirow[t]{2}{*}{ Sig. } \\
\hline & $\mathrm{B}$ & Std. Error & Beta & & \\
\hline (Constant) & 1.722 & 1.031 & & 1.670 & .099 \\
\hline Deskripsi pekerjaan & -.071 & .043 & -.217 & -1.662 & .101 \\
\hline Pengawasan & -.030 & .045 & -.090 & -.661 & .511 \\
\hline Pengembangan karir & .075 & .056 & .189 & 1.322 & .190 \\
\hline
\end{tabular}

Berdasarkan Tabel 5, diketahui regresi variabel independen terhadap absolute residual dan diperoleh hasilnya untuk variabel deskripsi pekerjaan nilai signifikansi $0,101>0,05$, variabel pengawasan nilai signifikansi $0,511>$ 0,05 , dan variabel pengembangan karir nilai signifkansi $0,190>0,05$. Dengan demikian dapat disimpulkan bahwa tidak terdapat adanya heterokedastisitas dalam model regresi.

\section{Hasil Pengujian Hipotesis}

\subsection{Analisis Regresi Linear Berganda}

Metode analisis regresi berganda digunakan untuk mengetahui berapa besar pengaruh variabel bebas (deskripsi pekerjaan, pengawasan dan pengembangan karir) terhadap variabel terikat (komitmen organisasi). Data diolah secara statistik untuk keperluan analisis dan pengujian hipotesis dengan menggunakan alat bantu program SPSS 20.0 for windows.

Tabel 6. Hasil Regresi Linear Berganda

\begin{tabular}{|ll|r|r|}
\hline \multirow{2}{*}{ Model } & \multicolumn{2}{|c|}{ Unstandardized Coefficients } \\
\cline { 2 - 4 } & \multicolumn{2}{|c|}{ B } & \multicolumn{1}{c|}{ Std. Error } \\
\hline \multirow{3}{*}{1 (Constant) } & 2.517 & 1.842 \\
& Deskripsi pekerjaan & .152 & .076 \\
& Pengawasan & .428 & .080 \\
& Pengembangan karir & .482 & .101 \\
\hline
\end{tabular}

Berdasarkan Tabel 6 diketahui pada kolom kedua (unstandardized Coefficients) bagian $\mathrm{B}$, diperoleh nilai koefisien regresi $\mathrm{b}_{1}$ (variabel deskripsi pekerjaan) sebesar 0,152 , koefisien regresi $b_{2}$ (variabel pengawasan) sebesar 0,428 , koefisien regresi $b_{3}$ (variabel pengembangan karir) sebesar 0,482 , dan nilai konstanta (a) adalah 2,517. Maka diperoleh persamaan regresi linier berganda sebagai berikut : 
$Y=2,517+0,152 X_{1}+0,428 X_{2}+0,482 X_{3}+e$

Interpretasi persamaan diatas dapat dijelaskan sebagai berikut :

1) Konstanta (a) $=2,517$ menunjukkan nilai konstan, jika nilai variabel bebas (deskripsi pekerjaan, pengawasan dan pengembangan karir) tidak ada atau bernilai nol maka komitmen organisasi sebesar 2,517 satuan.

2) Koefisien $X_{1}\left(b_{1}\right)=0,152$, ini berarti bahwa variabel deskripsi pekerjaan berpengaruh positif terhadap organisasi, atau dengan kata lain jika deskripsi pekerjaan ditingkatkan sebesar satu satuan, maka komitmen organisasi akan meningkat sebesar 0,152 satuan.

3) Koefisien $X_{2}\left(b_{2}\right)=0,428$, ini berarti bahwa variabel pengawasan berpengaruh positif terhadap komitmen organisasi, atau dengan kata lain jika pengawasan ditingkatkan sebesar satu satuan, maka komitmen organisasi akan menigkat sebesar 0,428 satuan.

4) Koefisien $X_{3}\left(b_{3}\right)=0,482$, ini berarti bahwa variabel pengembangan karir berpengaruh positif terhadap komitmen organisasi, atau dengan kata lain jika pengembangan karir ditingkatkan sebesar satu satuan, maka komitmen organisasi akan menigkat sebesar 0,482 satuan.

\subsection{Uji Signifikansi Parsial (Uji t)}

Uji $\mathrm{t}$ dilakukan untuk menguji secara parsial apakah deskripsi pekerjaan $\left(\mathrm{X}_{1}\right)$, pengawasan $\left(\mathrm{X}_{2}\right)$ dan pengembangan karir secara parsial atau individual berpengaruh signifikan terhadap komitmen organisasi (Y).

Kriteria pengujian adalah :

1) Ho : $b_{1}, b_{2}, b_{3}=0$, artinya secara parsial deskripsi pekerjaan, pengawasan dan pengembangan karir tidak berpengaruh terhadap komitmen organisasi.

2) Ha : $b_{1}, b_{2}, b_{3} \neq 0$, artinya secara parsial deskripsi pekerjaan, pengawasan dan pengembangan karir berpengaruh terhadap komitmen organisasi.

Kriteria pengambilan keputusan adalah :

1) $\mathrm{H}_{0}$ diterima jika $t_{\text {htitung }}<t_{\text {tabel }}$ pada $\alpha=5 \%$

2) $\mathrm{H}_{0}$ ditolak jika $t_{\text {hitung }}>t_{\text {tabel }}$ pada $\alpha=5 \%$

Besar nilai $t_{\text {tabel }}$ dengan derajat bebas $(\mathrm{df})=$ $\mathrm{n}-\mathrm{k}=75-4=71$ adalah 1,667. Hasil uji t dapat dilihat pada Tabel 5.12 sebagai berikut ini

Tabel 7. Hasil Uji t

Coefficients $^{\mathrm{a}}$

\begin{tabular}{|l|r|r|r|r|r|}
\hline \multirow{2}{*}{ Model } & \multicolumn{2}{|l|}{ Unstandardized Coefficients } & $\begin{array}{c}\text { Standardized } \\
\text { Coefficients }\end{array}$ & \multirow{2}{*}{$\mathrm{t}$} & Sig. \\
\cline { 2 - 5 } & \multicolumn{1}{|c|}{$\mathrm{B}$} & Std. Error & \multicolumn{1}{c|}{ Beta } & & \\
\hline \multirow{2}{*}{ (Constant) } & 2.517 & 1.842 & & 1.366 & .176 \\
1 & .152 & .076 & .156 & 2.002 & .049 \\
Deskripsi pekerjaan & .428 & .080 & .434 & 5.333 & .000 \\
Pengawasan & .482 & .101 & .407 & 4.786 & .000 \\
\hline
\end{tabular}

a. Dependent Variable: Komitmen organisasi

Melalui Tabel 7 hasil uji signifikan secara parsial dapat diambil kesimpulan yaitu :

1) Pengaruh Deskripsi Pekerjaan terhadap Komitmen Organisasi

Untuk variabel deskripsi pekerjaan diperoleh nilai $t_{\text {hitung }}$ sebesar 2,002 dengan taraf signifikansi sebesar 0,049. Dengan demikian nilai $t_{\text {hitung }}(2,002)>t_{\text {tabel }}(1,667)$ dengan taraf signifikansi $0,049<0,05$. Artinya bahwa deskripsi pekerjaan berpengaruh signifikan terhadap komitmen organisasi. Kesimpulannya hipotesis diterima.

2) Pengaruh Pengawasan terhadap Komitmen Organisasi

Variabel pengawasan diperoleh nilai $\mathrm{t}_{\text {hitung }}$ sebesar 5,333 dengan taraf signifikansi sebesar 0,000 . Dengan demikian nilai $t_{\text {hitung }}$ $(5,333)>t_{\text {tabel }}(1,667)$ dengan taraf signifikansi $0,000<0,05$. Artinya bahwa pengawasan berpengaruh signifikan terhadap komitmen organisasi. Kesimpulannya hipotesis diterima.

3) Pengaruh Pengembangan Karir terhadap Komitmen Organisasi

Variabel pengembangan karir diperoleh nilai $t_{\text {hitung }}$ sebesar 4,786 dengan taraf signifikansi sebesar 0,000 . Dengan demikian nilai $t_{\text {hitung }}$ $(4,786)>t_{\text {tabel }}(1,667)$ dengan taraf signifikansi $0,000<0,05$. Artinya bahwa pengembangan karir berpengaruh signifikan terhadap komitmen organisasi. Kesimpulannya hipotesis diterima. 


\subsection{Uji Signifikansi Simultan (Uji F)}

Pengujian ini dilakukan untuk melihat secara bersama-sama pengaruh atau hubungan positif dan signifikan variabel bebas berupa deskripsi pekerjaan, pengawasan dan pengembangan karir terhadap variabel terikat yaitu komitmen organisasi.

Model hipotesis yang digunakan dalam Uji $F$ ini adalah sebagai berikut :

1) Ho: $b_{1}=b_{2}=b_{3}=0$, artinya secara simultan deskripsi pekerjaan, pengawasan dan pengembangan karir tidak berpengaruh terhadap komitmen organisasi.

2) Ho: $b_{1} \neq b_{2} \neq b_{3} \neq 0$, artinya secara serentak simultan deskripsi pekerjaan, pengawasan dan pengembangan karir berpengaruh terhadap komitmen organisasi.

Tabel 8 Hasil Uji F ANOVA $^{\mathrm{a}}$

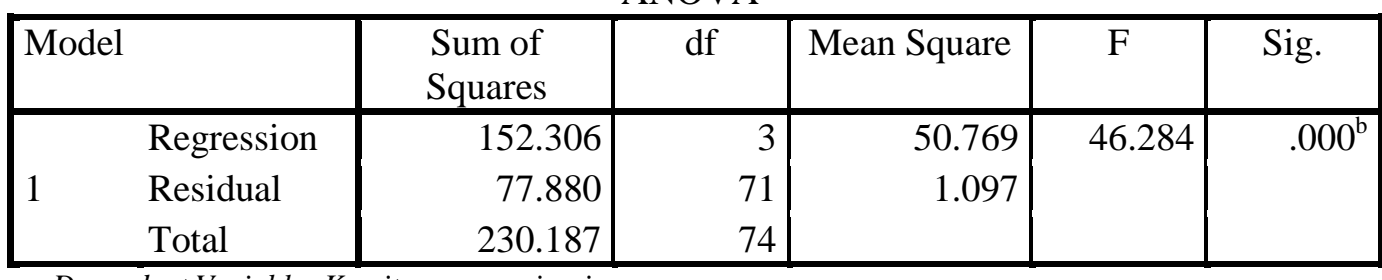

a. Dependent Variable: Komitmen organisasi

b. Predictors: (Constant), Pengembangan karir, Deskripsi pekerjaan, Pengawasan

Melalui uji ANOVA atau F-test pada Tabel 8, diperoleh nilai $F_{\text {hitung }}$ sebesar 46,284 dengan tingkat signifikansi 0,000 . Maka $F_{\text {hitung }}(46,284)$ $>\mathrm{F}_{\text {tabel }}(2,734)$ dengan signifikansi $0,000<$ 0,05 . Berdasarkan hasil tersebut dapat disimpulkan bahwa deskripsi pekerjaan, pengawasan dan pengembangan karir secara simultan berpengaruh signifikan terhadap

Tabel 9. Koefisien Determinan

Model Summary ${ }^{\mathrm{b}}$

\begin{tabular}{|l|r|r|r|r|}
\hline Model & \multicolumn{1}{|c|}{$\mathrm{R}$} & R Square & $\begin{array}{c}\text { Adjusted R } \\
\text { Square }\end{array}$ & $\begin{array}{c}\text { Std. Error of } \\
\text { the Estimate }\end{array}$ \\
\hline 1 & $.813^{\mathrm{a}}$ & .662 & .647 & 1.047 \\
\hline
\end{tabular}

Pengawasan

b. Dependent Variable: Komitmen organisasi

1) Nilai $R$ sebesar 0,813 berarti hubungan antara variabel deskripsi pekerjaan, pengawasan dan pengembangan karir terhadap variabel komitmen organisasi sebesar $81,3 \%$. Artinya hubungannya sangat erat.

2) Nilai Adjusted $R$ Square 0,647 berarti $64,7 \%$ komitmen organisasi dapat di jelaskan oleh deskripsi pekerjaan, pengawasan dan pengembangan karir, sedangkan sisanya komitmen organisasi. Kesimpulannya hipotesis dapat diterima.

\subsection{Uji Determinan}

Hasil pengujian koefisien determinasi menggunakan SPSS dapat dilihat pada Tabel 9 dibawah ini :
Kriteria pengambilan keputusan sebagai berikut :

1) Ho diterima jika $F_{\text {hitung }}<F_{\text {tabel }}$ pada $\alpha=5 \%$

diperlukan adanya derajat bebas pembilang adalah jumlah sampel penelitian, dan $k$ adalah jumlah variabel. Pada penelitian ini jumlah n) adalah 75 dan jumlah keseluruhan $75-4=71$. Maka nilai $F_{\text {tabel }} 0,05(3: 71)=$ 2,734 . 
$(2,002)>t_{\text {tabel }}(1,667)$ dengan taraf signifikansi $0,049<0,05$. Berdasarkan analisis regresi linear berganda, deskripsi pekerjaan memiliki pengaruh yang paling kecil terhadap komitmen organisasi dibandingkan variabel yang lain. Berdasarkan analisis deskriptif diketahui bahwa mayoritas responden memberikan tanggapan "setuju" dan "sangat setuju" atas semua pernyataan variabel deskripsi pekerjaan diketahui responden memberikan jawaban yang beragam terhadap semua pernyataan. Akan tetapi pada pernyataan nomor 1 (Dalam deskripsi pekerjaan memuat dengan jelas tugas anggota polisi) responden yang memberikan jawaban kurang setuju cukup banyak yaitu 29 orang $(38,7 \%)$. Hal ini menunjukan bahwa masih ada anggota polisi yang kurang memahami dengan baik tugas dan fungsinya. Deskripsi pekerjaan yang tidak terlaksana dengan baik dikarenakan kurangnya kemampuan dalam memahami dan menguasai tugas.

Deskripsi kerja adalah keseluruhan kajian ringkasan informasi pekerjaan dan syarat-syarat pelaksanaan seorang karyawan sebagai hasil dari analisis yang berisi tugas pokok dari uraian pekerjaan (Rivai, 2014:126). Hasibuan (2012:32) menjelaskan apabila deskripsi kerja kurang jelas akan mengakibatkan seorang pegawai kurang mengetahui tugas dan tanggung jawabnya pada pekerjaan itu, mengakibatkan pekerjaan tidak terlaksana dengan baik. Dengan adanya perancangan pekerjaan dan deskripsi tugas yang jelas, maka pegawai akan semakin produktif dan berprestasi sehingga keuntungan ekonomis dari deskripsi pekerjaan akan diperoleh.

\subsection{Pengaruh Pengawasan Terhadap Komitmen Organisasi Polisi di Kepolisian Resor Labuhanbatu}

Berdasarkan hasil penelitian diketahui bahwa pengawasan berpengaruh positif dan signifikan terhadap komitmen organisasi polisi di Kepolisian Resor Labuhanbatu, dimana nilai $t_{\text {hitung }}(5,333)>t_{\text {tabel }}(1,667)$ dengan taraf signifikansi $0,000<0,05$. Berdasarkan distribusi jawaban responden terhadap variabel pengawasan diketahui mayoritas responden memberikan jawaban setuju terhadap semua pernyataan, meskipun pada pernyataan nomor 1 (Institusi kepolisian memiliki standar operasional prosedur yang baku) cukup banyak responden yang menjawab kurang setuju yaitu 28 orang $(37,3 \%)$ dan menjawab tidak setuju ada 1 orang $(1,3 \%)$. Hal ini menunjukkan bahwa masih ada anggota polisi yang tida mengetahui standar operasional prosedur yang baku di kepolisian. Selain itu, dalam observasi yang dilakukan peneliti melihat bahwa pimpinan kurang efektif melakukan koreksi terhadap anggota, dimana apabila ditemukan kesalahan dalam pekerjaan tidak segera dilakukan tindakan koreksi atau perbaikan sebagai wujud umpan balik dari pengawasan yang dilakukan sehingga penyelesaian pekerjaan membutuhkan waktu lebih lama dan tujuan organisasi tidak tercapai sesuai dengan yang telah ditetapkan. Apabila tindakan pembanding dan tindakan korektif dari pengawasan tidak segera diperbaiki maka akan mengakibatkan pegawai tersebut akan mengulang kesalahan yang sama dan berdampak terhadap menurunnya komitmen organisasi.

Pengawasan merupakan bagian dari fungsi manajemen yang khususnya berupaya agar rencana yang sudah ditetapkan dapat tercapai sebagaimana mestinya. Schermerhorn (dalam Sule dan Saefullah, 2010:317) mendifinisikan pengawasan merupakan proses dalam menetapkan ukuran kinerja dalam pengambilan tindakan yang dapat mendukung pencapaian hasil yang diharapkan sesuai dengan ukuran yang telah ditetapkan. Secara filosofis dikatakan bahwa pengawasan sangat penting karena manusia pada dasarnya mempunyai sifat salah atau khilaf, sehingga manusia dalam organisasi perlu diawasi, bukan untuk mencari kesalahannya kemudian menghukumnya tetapi untuk mendidik dan membimbingnya.

\subsection{Pengaruh Pengembangan Karir Terhadap Komitmen Organisasi Polisi di Kepolisian Resor Labuhanbatu}

Berdasarkan hasil penelitian diketahui bahwa pengembangan karir berpengaruh positif dan signifikan terhadap komitmen organisasi polisi di Kepolisian Resor Labuhanbatu, nilai $t_{\text {hitung }}(4,786)>t_{\text {tabel }}(1,667)$ dengan taraf signifikansi $0,000<0,05$. Berdasarkan analisis regresi linear berganda, pengembangan karir merupakan variabel yang paling dominan (kuat) berpengaruh terhadap komitmen organisasi dimana hasil koefisien regresinya paling besar. Hasil ini menunjukkan bahwa sistem pengembangan karir di kepolisian sudah berjlan baik dan baku dari mulai pusat sampai daerah. Sistem pengembangan karir karir di kepolisian didasarkan atas kepangkatan dan prestasi kerja. 
Berdasarkan analisis deskriptif mayoritas responden memberikan tanggapan "sangat setuju" dan "setuju" terhadap semua pernyataan, dan hanya sedikit yang memberikan tanggapan "kurang setuju".

Karir seorang adalah cerminan dari perkembangan dirinya secara individu dalam jenjang jabatan yang dapat dicapai selama masa kerja dalam organisasi yang bersangkutan. Maka dari itu suatu karir menunjukkan peran masing-masing orang atau status mereka dalam organisasi tersebut. Pengembangan karir menurut Robbins (2014) adalah suatu yang menunjukkan adanya peningkatan-peningkatan status seseorang dalam suatu organisasi dalam jalur karir yang telah ditetapkan dalam organisasi yang bersangkutan. Namun pengembangan karir seseorang dalam suatu organisasi tentunya tidak sama, karena amat tergantung dari berbagai faktor. Setiap individu (pegawai/karyawan) akan melihat pengembangan karir mereka berdasarkan pengalaman yang mereka dapat selama bekerja di organisasi yang bersangkutan. Bagaimana pegawai memandang tanggung jawab, jabatan dan wewenang yang mereka miliki akan memepengaruhi tingkat komitmen mereka. Komitmen kerja yang tinggi akan dimiliki oleh pegawai, jika organisasi menjanjikan dalam hal pengembangan terhadap karir, namun berbeda dengan organisasi yang tidak menjanjikan pengembangan karir terhadap pegawainya.

Maka dari itu pengembangan karir selain akan memacu motivasi pegawai juga akan membuat pegawai ingin tetap bekerja dan membantu perusahaan untuk mencapai tujuannya. Hasil penelitian sejalan dengan penelitian Dicky Surya Handoko dan Muis Fauzi Rambe (2018) yang menyimpulkan bahwa pengaruh pengembangan karir terhadap komitmen organisasi berpengaruh secara positif dan signifikan.

\subsection{Pengaruh Deskripsi Pekerjaan, Pengawasan dan Pengembangan Karir Terhadap Komitmen Organisasi Polisi di Kepolisian Resor Labuhanbatu}

Hasil penelitian menunjukkan bahwa deskripsi pekerjaan, pengawasan dan pengembangan karir secara simultan berpengaruh positif dan signifikan terhadap komitmen organisasi polisi di Kepolisian Resor Labuhanbatu, dimana nilai $F_{\text {hitung }}(46,284)>$ $F_{\text {tabel }}(2,734)$ dengan signifikansi $0,000<0,05$. Komitmen organisasi polisi dapat dipengaruhi oleh deskripsi pekerjaan, pengawasan dan pengembangan karir sebesar $64,7 \%$, sedangkan sisanya $35,3 \%$ komitmen organisasi dipengaruhi oleh faktor-faktor lain diluar variabel penelitian. Hal ini menunjukkan bahwa kontribusi variabel bebas terhadap variabel terikat sangat besar.

Hasil penelitian ini dapat mendukung penelitian sebelumnya oleh Sarsono dan Suseno (2012) yang menyimpulkan bahwa deskripsi kerja berpengaruh positif dan signifikan terhadap prestasi kerja, penelitian Dicky Surya Handoko dan Muis Fauzi Rambe (2018) yang menyimpulkan bahwa pengaruh pengembangan karir terhadap komitmen organisasi berpengaruh secara positif dan signifikan, penelitian Tri Joko (2019) yang menyimpulkan bahwa pengawasan berpengaruh positif dan signifikan terhadap kinerja pegawai.

\section{Kesimpulan}

Berdasarkan hasil analisis yang telah dilakukan, maka penulis dapat mengambil beberapa kesimpulan sebagai berikut :

1) Deskripsi pekerjaan berpengaruh positif dan signifikan terhadap komitmen organisasi polisi di Kepolisian Resor Labuhanbatu.

2) Pengawasan berpengaruh positif dan signifikan terhadap komitmen organisasi polisi di Kepolisian Resor Labuhanbatu.

3) Pengembangan karir berpengaruh positif dan signifikan terhadap komitmen organisasi polisi di Kepolisian Resor Labuhanbatu.

4) Deskripsi pekerjaan, pengawasan dan pengembangan karir secara simultan berpengaruh positif dan signifikan terhadap komitmen organisasi polisi di Kepolisian Resor Labuhanbatu.

5) Nilai Adjusted $R$ Square sebesar 0,647 menunjukkan komitmen organisasi polisi dapat dipengaruhi oleh deskripsi pekerjaan, pengawasan dan pengembangan karir sebesar $64,7 \%$, sedangkan sisanya $35,3 \%$ komitmen organisasi dipengaruhi oleh faktor-faktor lain diluar variabel penelitian, seperti kepuasan kerja, lingkungan kerja, iklim organisasi dan lain sebagainya.

\section{DAFTAR PUSTAKA}

Ali, Andi Adryan. (2012). "Analisis Pengaruh Pengembangan Karir Organisasi Terhadap Komitmen Karyawan Pada Kantor Pusat PT. Bank Sulselbar Kota Makassar". Skripsi. FEB Unhas. Makassar. 
Dessler, Gary. (2015). Manajemen Sumber Daya Manusia. Jakarta : Salemba Empat.

Durianto, Darmadi., Sugiarto, Tony Simanjuntak. (2013). "Strategi Menaklukkan Pasar Melalui Riset Ekuitas dan Perilaku Merek". Jakarta : Gramedia Pustaka Utama.

Ghozali, Imam. (2013). Aplikasi Analisis Multivariate dengan Program SPSS. Semarang : Badan Penerbit Universitas Diponegoro.

Gomes, Faustino Cardoso. (2013). Manajemen Sumber Daya Manusia. Yogyakarta : Andi.

Griffin, Ricky W, (2011). Manajemen, Edisi Ketujuh, Jilid Dua. Jakarta : Erlangga.

Handoko, T Hani. (2012). Manajemen Personalia \& Sumberdaya. Yogyakarta : BPFE.

Handoko, Dicky Surya dan Muis Fauzi Rambe. (2018). "Pengaruh Pengembangan Karir dan Kompensasi terhadap Komitmen Organisasi Melalui Kepuasan Kerja”. Jurnal Ilmiah Magister Manajemen, Vol 1, No. 1, September 2018, 31-45.

Harahap, Sofyan Safri. (2011). Sistem Pengawasan Manajemen. Jakarta : Penerbit Quantum.

Hariandja, Marihot Tua Effendi, (2014). Manajemen Sumber Daya Manusia. Yogyakarta : BPFE.

Hasibuan, Malayu S.P. (2012). Manajemen Sumber Daya Manusia. Jakarta : Bumi Aksara.

Husein Umar. (2013). Metode Penelitian untuk Skripsi dan Tesis. Jakarta : Rajawali.

Ismail, Iriani. (2015). Manajemen Sumber Daya Manusia. Malang : Lembaga Penerbitan Fakultas Pertanian Brawijaya.

Jaya, Rendra Kusuma dan Sulastri, Antoni. (2014). "Pengaruh Pengembangan Karir dan Konflik Peran terhadap Komitmen Organisasi Pegawai Sekretariat Daerah Kab. Kerinci dengan Kepuasan Kerja sebagai Variabel Intervening". Universitas Bung Hatta.

Joko, Tri. (2019). "Pengaruh Pengembangan Karir, Pengawasan dan Komitmen Pegawai Terhadap Kinerja Pegawai Di Dinas Pengendalian Penduduk dan Keluarga Berencana Kabupaten Bantaeng”. Journal of Management Volume 2 No. 22019.

Kuncoro, Mudrajat. (2013). Metode Riset Untuk Bisnis dan Ekonomi. Jakarta : Erlangga.

Luthans, Fred. (2012). Perilaku Organisasi. Yogyakarta : Penerbit Andi.
Manullang, M. (2014). Manajemen Sumber Daya Manusia. Yogyakarta : BBPE.

Masry, S. Maringan. (2013). Dasar-Dasar Administrasi dan Manajemen. Jakarta : Ghalia Indonesia.

Mathis, Robert dan Jackson, John. (2012). Manajemen Sumber Daya Manusia. Terjemahan Jimmi Sadili dan Bayu. Jakarta : Salemba Empat.

Melina Taurisa, Cahterina dan Intan Ratnawati. (2012). "Analisis Pengaruh Budaya Organisasi dan Kepuasan Kerja terhadap Komitmen Organisasional dalam Meningkatkan Kinerja Karyawan. Universitas Diponegoro.

Mitha, Risnawati dan Suryalena. (2018). "Pengaruh Pengembangan Karir dan Komitmen Organisasi Terhadap Kinerja Karyawan Pada Hotel Mutiara Merdeka Pekanbaru. JOM FISIP Vol. 5: Edisi II Juli Desember 2018.

Moekijat. (2012). Analisis Jabatan. Bandung : CV. Mandar Madju.

Mulyadi. (2013). Sistem Perencanaan dan Pengendalian Manajemen. Jakarta : Salemba Empat.

Putra, Fadhlillah Dali. (2014). "Analisis Pengaruh Kompensasi, Pengembangan Karir, Dan Lingkungan Kerja Non Fisik Terhadap Komitmen Organisasional (Studi Pada PT Windika Utama Semarang)". Skripsi. FEB Undip. Semarang.

Rahmat, Aulia. (2011) "Pengaruh Pengawasan dan Evaluasi Terhadap Efisiensi Kerja Karyawan CV. Aulia Karya Utama Sibolga". Naskah Publikasi. Medan : Universitas Sumatera Utara.

Rivai, Veithzal. (2014). Manajemen Sumber Daya Manusia untuk Perusahaan. Edisi ke-6. Jakarta : PT. Raja Grafindo Persada.

Robbins \& Judge. (2012). Perilaku Organisasi, Edisi 12. Jakarta : Salemba Empat.

Robbins, Stephen P dan Coulter, Mary. (2014). Management. Jakarta : Erlangga.

Sarsono dan Suseno. (2012). "Pengaruh Deskripsi Pekerjaan dan Pengembangan Karir Terhadap Prestasi Kerja dengan Kepuasan Kerja sebagai Variabel Moderasi". Jurnal Fakultas Ekonomi. Universitas Slamet Riyadi Surakarta.

Sopiah, (2013). Perilaku Organisasional, Edisi ketiga. Yogyakarta : Andi Offset.

Sudarmanto. (2014). Kinerja \& Pengembangan Kompetensi SDM. Yogyakarta : Pustaka Pelajar. 
Sule, Tisnawati, Ernie dan Kurniawan Saefullah. (2012). Pengantar Manajemen. Jakarta : Prenada Media.

Sugiyono. (2012). Metode Penelitian Bisnis. Bandung : Penerbit Alfabeta.

Sunyoto, Danang. (2013). Manajemen Sumber Daya Manusia. APS (Center For Academic Publishing Service), Yogyakarta.

Tyson, Shaun \& Tony Jackson. (2012). Perilaku Organisasi. Yogyakarta : Penerbit Andi.

Umam, Khaerul. (2012). Perilaku Organisasi. Bandung : CV. Pustaka Setia.

Yuli, Cantika Budi Sri. (2013). Manajemen Sumber daya Manusia. Cetakan kedua. Malang : Universitas Muhammadiyah. 